\title{
Increased Expression of PITX2, LEF-1, $\beta$-Catenin in Epithelial Ovarian Cancer
}

Huanhuan Guo, Hai Zhu, Shujun Zhao, Min Zhang, Xingshuo Liu, Huihui Han, Meng Cao, Li Dong and Hongyu Li*

Department of Obstetrics and Gynecology, The Third Affiliated Hospital of Zhengzhou University, Zhengzhou, PR China

\begin{abstract}
Objective: Pituitary homeobox-2 (PITX2), a member of the bicoid/paired-like homeobox gene family, plays an important role in determining left-right asymmetry in vertebrates and development of multiple organs by serving as a downstream effector of Nodal, TGF $\beta$, and Wnt signaling pathway. PITX2, lymphoid enhancer factor (LEF-1) and beta-catenin are required for the inductive formation of several epithelial-derived organs, including teeth, which remains unclear interaction Wnt signal pathway in the development of ovarian epithelial tumors. Research PITX2, LEF-1 and beta-catenin direct interactions may provide new mechanisms for epithelial ovarian cancer.
\end{abstract}

Materials and methods: 1 . Using immunohistochemical (IHC), real-time quantitative RT-PCR (Q-PCR), Western blot to analyse the expression of PITX2, LEF-1, $\beta$-catenin in ovarian cancer tissues and cell lines. 2. Using Enzymelinked immunosorbent assay (ELISA) to detect the expression of PITX2 in serum of epithelial ovarian cancer. 3. Using MTT to investigate cell's proliferation and migration.

Results: 1. The protein and mRNA in PITX2, LEF-1, $\beta$-catenin frequently overexpress in ovarian cancer samples and cell lines. Low or no expression in benign ovarian tumors and normal ovarian samples $(p<0.05)$. 2 . The preoperative serum levels of PITX2 in ovarian cancer groups was higher than benign ovarian tumors and normal ovarian samples $(p<0.05)$, and the levels of PITX2 in preoperative serum in ovarian cancer groups were significantly higher than the postoperative groups $(p<0.05)$.

Conclusion: PITX2 is involved in the occurrence and development of epithelial ovarian cancer, and PITX2 may act as a downstream target genes in the $\mathrm{Wnt} / \beta$-catenin signaling pathway, which is regulated by $\mathrm{Wnt} / \beta$-catenin. The high expression of PITX2 protein in the serum of patients with epithelial ovarian cancer, suggesting that PITX2 may serve as a good indicator of early diagnosis and evaluation of disease progression in patients with epithelial ovarian cancer.

Keywords: PITX2; LEF-1; $\beta$-catenin; Gene expression; Epithelial ovarian cancer

\section{Introduction}

Ovarian cancer is one of the three most common female genital cancers in the world, with its mortality rate highest among the others. About $90 \%$ ovarian cancer comes from epithelia. The five years survival rate is still hovering around $25 \%-30 \%$ due to the late diagnosis and poor therapeutic response. Ovarian hidden in the pelvic, epithelial ovarian cancer is poor prognosis, $70 \% \sim 80 \%$ advanced stage, we occurs it easily transfer and diffusion. However, even after complete tumor debulking surgery, the cancer's recurrence rate is still high. Epithelial ovarian cancer has become a type of serious tumor that threatens women's lives [1-7]. Early detection and effective suppression of ovarian tumor's invasion and metastasis, which lead to an increase of the survival rate of patients in the long run, will open up new ideas for the treatment of epithelial ovarian cancer.

PITX2, located on chromosome $4 \mathrm{q} 25-26$, is a member of the bicoid homeodomain family, the origin of the function in pituitary development, which plays an important role in embryogenesis, pituitary, eye, teeth and heart of vertebrates. Several studies have reported that mutation of PITX2 is associated with the pathogenesis of AxenfeldRieger syndrome (ARS), iridogonio dysgenesis syndrome, sporadic Peter syndrome, and so on $[8,9]$. Previous studies have pointed out that PITX2 is one of the downstream effectors of $\mathrm{Wnt} / \beta$-catenin pathway and PITX2 may be regulated by canonical b-catenin pathway [10-12]. As we all know, Wnt signaling pathway is playing an important role in the development of ovarian cancer, but the relationship between PITX2 in ovarian cancer remains unclear.

Lymphocyte enhancer factor (LEF1) is located on human chromosome 4q23-25 region, which is a high mobility group (HMG) transcription factor, one of lymphoid enhancer factor/T-cell factor transcription factor family member, was found as lymphoid-specific transcription factors and closely associated with the differentiation of thymocytes.it collaborates with other DNA-binding proteins activates transcription. In recent years, studies have reported that $\beta$-catenin can bind the TCF/LEF family of transcription factors, displacing a corepressor and changing them to activators of transcription [4]. LEF-1 is a key nuclear transcription factor in wnt $/ \beta$-catenin signaling pathway,which abnormalities expression is associated with multiple tumors,such as osteosarcoma[13], breast cancer [14,15], colon cancer [16] and melanoma [17] etc.

In a present study, PITX2 and LEF-1 have specific binding sites in the development of pituitary gland. LEF-1 is a downstream target of PITX2. PITX2 and $\beta$-catenin directly interact to regulate LEF-1 expression [4]: when stimulated by wnt signaling pathway, PITX2 transcriptional activity is enhanced; on the contrary, PITX2 cannot transcribe. However, currently, it has not been reported in epithelial ovarian cancer. The present study was to investigate the relationship of

*Corresponding author: Hongyu Li, Department of Obstetrics and Gynecology, The Third Affiliated Hospital of Zhengzhou University, Zhengzhou, PR China, Tel: 86 15936257242; E-mail: lihongyu99@qq.com

Received April 12, 2015; Accepted June 11, 2015; Published June 13, 2015.

Citation: Guo H, Zhu H, Zhao S, Zhang M, Liu X, et al. (2015) Increased Expression of PITX2, LEF-1, $\beta$-Catenin in Epithelial Ovarian Cancer. J Cytol Histol 6: 333. doi:10.4172/2157-7099.1000333

Copyright: (C) $2015 \mathrm{Guo} \mathrm{H}$, et al. This is an open-access article distributed under the terms of the Creative Commons Attribution License, which permits unrestricted use, distribution, and reproduction in any medium, provided the original author and source are credited. 
Citation: Guo H, Zhu H, Zhao S, Zhang M, Liu X, et al. (2015) Increased Expression of PITX2, LEF-1, $\beta$-Catenin in Epithelial Ovarian Cancer. J Cytol Histol 6: 333. doi:10.4172/2157-7099.1000333

Page 2 of 6

PITX2, LEF-1 and b-catenin in the development of epithelial ovarian cancer. When add the DKK1 (wnt signaling pathway inhibitor) in the cells, PITX2 and LEF-1 transcriptional activity are weakened.

\section{Materials and Methods}

\section{Clinical samples}

Surgical resection of 114 tumor samples from the Third Affiliated Hospital of Zhengzhou University dated from September 2012 to December 2014. The age of the patients were from 16 to 70 years old, with a mean of 49.79 years old. According to the classification of the International Federation of Gynaecology and Obstetrics (FIGO), clinical samples were divided into three groups: 42 cases of epithelial ovarian cancer (the stage of I II and III IV is respective 15 and 17 cases), 37 cases of epithelial ovarian benign tumor, and 35 cases of normal ovarian ,All the tissue specimens were fixed in $10 \%$ formalin and embedded in paraffin. 114 Blood samples were collected from 6:00 am to $8: 00 \mathrm{am}$. The samples stayed at room temperature for $20 \mathrm{~min}$, and centrifuged by $3000 \mathrm{r} / \mathrm{min}$ under $4^{\circ} \mathrm{C}$ for $20 \mathrm{~min}$, and then finally took Serum samples to the EP tubes, staged in $-80^{\circ} \mathrm{C}$. 114 cases were not associated with other cancers, preoperative and postoperative were not receiving radiotherapy and chemotherapy, Signature were obtained from all 114 cases, either from the patient or the patient's family.114 samples confirmed by postoperative pathology diagnosis.

\section{Cell lines}

SKOV-3, OVCAR3 (ATCC, Manassas, VA), both were supplemented with $10 \%$ fetal bovine serum (FBS, Invitrogen), 100 units $/ \mathrm{ml}$ penicillin, and $100 \mu \mathrm{g} / \mathrm{ml}$ streptomycin (both Invitrogen) in $75 \mathrm{~cm}^{2}$ flasks and incubated at $37^{\circ} \mathrm{C}$ in $5 \% \mathrm{CO}_{2}$ added wnt pathway inhibitor DKK130 $\mathrm{ng} / \mathrm{ml}$ When the cells into the logarithmic phase. Cell groups: SKOV3 control group, SKOV3+DKK1 inhibitor group, OVCAR3 blank control group, OVCAR3+DKK1 inhibitor group.

\section{Immunohistochemical}

114 Ovarian tissue arrays were immunostained with primary rabbit polyclonal anti-PITX2 antibody (1:50 dilution), anti-LEF1 antibody (1:150 dilution) (SantaCruz Biotechnology,Inc., Santa Cruz,CA,USA) and primary rabbit polyclonal anti- $\beta$-catenin antibody (1:500 dilution) (AbcamInc,MA,USA). The stained section was identified as positive or negative. Random observation under the microscope 10 high power fields $(S P \times 400)$, counting 100 cells per field For those immunopositive samples, the intensity of the staining $(+1$ : faint; +2 : moderate; +3 : strong; +4: very strong), and the proportion of stained area (0$100 \%)$ were scored. Cancerous tissue staining intensity is $\geq 3$. Although staining intensity $=2$, the percentage of positive cells $\geq 10 \%$ are classified as positive. No matter what the positive rate is, cancerous tissue staining intensity $\leq 1$, are all negative [7] (Figure 1).
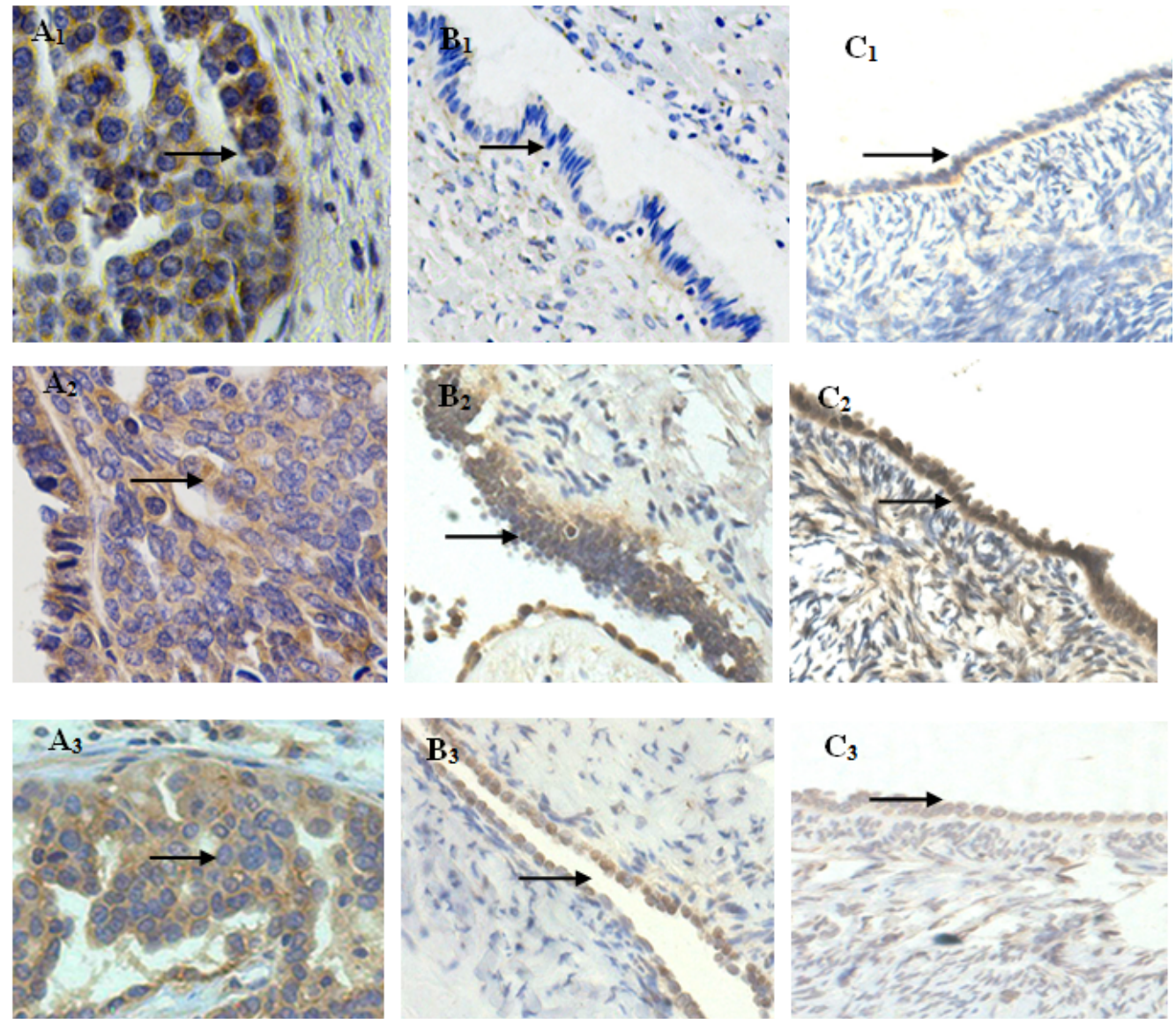

Figure1: Immunohistochemical (IHC) analysis of PITX2、LEF-1 and $\beta$-catenin expression in ovarian cancer samples, benign ovarian tumors and normal ovarian tissues. (magnification: 400X)

$\mathbf{A}_{1}$ : Positive expression of PITX2 in epithelial ovcarian cancer tissues; $\mathbf{B}_{1}$ : Negative expression of PITX2 in benign ovarian tumors; $\mathbf{C}_{1}$ : Negative expression of PITX2 in normal ovarian tissues; $\mathbf{A}_{2}$ : Positive expression of LEF-1 in epithelial ovcarian cancer tissues; $\mathbf{B}_{2}$ : Weakly negative expression of LEF-1 in benign ovarian tumors; $\mathbf{C}_{2}$ : Negative expression of LEF-1 in normal ovarian tissues; $\mathbf{A}_{3}$ : Positive abnormal expression of $\beta$-catenin in epithelial ovcarian cancer tissues; $B_{3}$ : Negative expression of $\beta$-catenin in benign ovarian tumors; $\mathbf{C}_{3}$ : Negative expression of $\beta$-catenin in normal ovarian tissues. 


\section{ELISA assay}

114 Serum samples arrays were in strict operated with the ELISA instructions (Bioss Biological Co.) Each sample was performed triplicate and three independent experiments were carried out. Finally, absorbance of each well were measured at $450 \mathrm{~nm}$ wavelength.

\section{Quantitative real time RT-PCR (Q-PCR)}

Total RNA from the clinical samples and the cultured cells was isolated using the TRIzol reagent. cDNA was prepared using Reverse transcription reagent kit (Applied Biosystems, Foster City, CA, USA). Relative expression levels of the specific genes were quantified by Q-PCR using power SYBR Green-I kit on the ABI 7500 Real Time PCR system (Applied Biosystems) after normalization with the expression of $18 \mathrm{~S}$ rRNA genes. $800 \mathrm{ng}$ of total RNA were isolated from tissue and cells, and were reverse-transcribed as mentioned above, followed by Q-PCR.After purification, PCR was used with the following conditions: Predenaturating $95^{\circ} \mathrm{C}$ for $60 \mathrm{~s}$, annealing at specific temperature for each set of primers $95^{\circ} \mathrm{C}$ for $15 \mathrm{~s}$, and $65^{\circ} \mathrm{C}$ for $45 \mathrm{~s}$, for 40 cycles. The information of Primers was mentioned in Table 1.

\section{Western blot analysis}

$10^{5}$ cells for SKOV3 and $2 \times 10^{5}$ cells for OVCAR3 seeded in a 6-well plate for $24 \mathrm{~h}$ added to the wnt pathway inhibitor DKK130 ng/ml. After $48 \mathrm{~h}$ the cells were scraped off by the brush. It was then centrifuged at $1200 \mathrm{Xg}$ for $10 \mathrm{~min}$ at $4^{\circ} \mathrm{C}$. Collected the supernatant, resolved on $10 \%$ SDS-PAGE (25), and subjected to immunoblotting with antibodies including anti- $\beta$-catenin (1:500 dilution), anti-active $\beta$-catenin (1:550 dilution), anti-LEF-1 (1:500 dilution) anti-PITX2(1:1000 dilution. The experiments were performed three times independently.

\section{Cell proliferation assays}

SKOV- 3 cells $\left(2 \times 10^{3}\right.$ cells/well $)$ and OVCAR-3cells $\left(3 \times 10^{3}\right.$ cells/ well) were seeded on a 96-well culture plate. Pretreated cells by DKK1 next day, after $6 \mathrm{~h}$, medium was discarded, washed with sterile PBS, the growth rate of cells was assessed by MTT assay kit (solarbio Biological Co). Photometric detected at $490 \mathrm{~nm}$ wavelength.

\section{Transwell cell migration}

SKOV-3cells $\left(3.4 \times 10^{5}\right.$ cells/well $)$ and OVCAR-3 cells $\left(2.5 \times 10^{5} \mathrm{cells} /\right.$ well) were seeded on a 6 -well culture plate that labeled with marker pen. After $24 \mathrm{~h}$, draw a line in the hole along with a ruler, washed with sterile PBS three times,pretreated cells by DKK1 (30 ng/ml), seeded in an incubator, pictured respectively $0,6,12,24 \mathrm{~h}$.Data analysis and processing by Image J.

\section{Data analysis}

Data were presented as mean \pm SD. Student's t-test, Chi-square test or Fisher exact test and ANOVA were used to analysis parametric data. The correlation of PITX2、LEF- 1 and $\beta$-catenin test were analysed by spearman correlation test. A P-value of $<0.05$ was considered significant in all experiment.

\section{Results}

\section{PITX2, LEF-1 and $\beta$-catenin overexpressed in epithelial ovarian cancer tissues}

Despite the functions of PITX2, LEF- 1 and $\beta$-catenin during other cancers have been extensively studied, the functional roles of these proteins in human cancers remain largely unknown. Here, Consistent with the immunohistochemical and Q-PCR findings, we evaluated the expression status of PITX2、LEF-1 and $\beta$-catenin in ovarian cancer samples, benign ovarian tumors and normal ovaries. Ovarian cancer cell lines including SKOV-3cells and OVCAR-3 cells. We found PITX2 、 LEF-1 and $\beta$-catenin were significantly overexpressed in ovarian cancer samples as compared with benign ovarian tumors and normal ovarian tissues $(\mathrm{P}<0.01)$ (Table 2). Clinicopathological correlation showed that overexpressed PITX2, LEF- 1 and $\beta$-catenin were remarkably associated with clinical stage, histological grade and lymph node metastasis $(\mathrm{P}<0.05)$. Whether there is lymph node metastasis in ovarian cancer, the datas of LEF-1 and $\beta$-catenin were close to the threshold, respectively $\mathrm{P}=0.045$ and $\mathrm{P}=0.044$, so this requires further experiments certification. However, there was no significant association between the overexpressed of PITX2, LEF-1, $\beta$-catenin and other parameters such as age and pathological type $(\mathrm{P}>0.05)$; the positive expression rate of III-IV stage was significantly higher than I-II stage $(\mathrm{P}<0.05)$, the expression of poorly differentiated was significantly higher than the Well differentiated and differentiated. There was no significant association between the Well differentiated and differentiated (Tables 3-5). ELISA data also showed that PITX2 was significantly overexpressed in ovarian cancer serum samples as compared with the serum of benign ovarian tumors and normal ovaries $(\mathrm{P}<0.05)$, but benign ovarian tumors and normal ovaries have no significant difference $(\mathrm{P}>0.05)$. Development of epithelial ovarian cancer may be associated with abnormal expression of these three genes.

\section{DKK1 inhibits cell growth and migration in ovarian cancer cells}

Previous studies have shown that $\mathrm{DKK}_{1}$ inhibits the Wnt/bcatenin signaling way; after added $\mathrm{DKK}_{1} 30 \mathrm{ng} / \mathrm{ml}$, the proliferation and migration of SKOV3 and OVCAR3 were significantly reduced

\begin{tabular}{|c|c|c|c|c|}
\hline Gene name & Forward primer $\left(5^{\prime} \rightarrow 3^{\prime}\right)$ & Reverse primer $\left(5^{\prime} \rightarrow 3^{\prime}\right)$ & Product size/bp & $\mathrm{Tm} /{ }^{\circ} \mathrm{C}$ \\
\hline PITX2 & СTCCAGTCTCAACAGCCTGA & ATACTGGCAAGCACTCAGGT & 226 & 59.0 \\
\hline LEF-1 & AAACCGAAGCGAAAGGGAAG & AACGAAACGTCCACTTCCTG & 113 & 58.0 \\
\hline$\beta$-catenin & TGGGACACAGCAGCAATTTG & AGCAGCTGCACAAACAATGG & 147 & 60.0 \\
\hline GAPDH & AGAAGGCTGGGGCTCATTTG & AGGGGCCATCCACAGTCTTC & 258 & 60.0 \\
\hline
\end{tabular}

Table 1: The primer details.

\begin{tabular}{|c|c|c|c|c|c|c|c|c|c|c|c|c|c|}
\hline \multirow{2}{*}{ Group } & \multirow{2}{*}{$\mathbf{n}$} & \multicolumn{4}{|c|}{ PITX2 } & \multicolumn{4}{|c|}{ LEF-1 } & \multicolumn{4}{|c|}{$\beta$-catenin } \\
\hline & & + & $(\%)$ & $x^{2}$ & $P$-value & + & $(\%)$ & $x^{2}$ & $P$-value & + & $(\%)$ & $x^{2}$ & $P$-value \\
\hline Cancer group & 42 & 35 & (83.33) & 51.072 & $<0.001$ & 32 & (76.19) & 37.928 & $<0.001$ & 36 & (85.71) & 68.462 & $<0.001$ \\
\hline Benign group & 37 & 6 & (16.21) & & & 8 & $(21.62)$ & & & 4 & (10.81) & & \\
\hline Normal group & 35 & 5 & (14.29) & & & 5 & (14.29) & & & 2 & $(5.71)$ & & \\
\hline
\end{tabular}

Table 2: The expressions of PITX2, LEF-1, $\beta$-catenin proteins in different ovarian tissues. 
Citation: Guo H, Zhu H, Zhao S, Zhang M, Liu X, et al. (2015) Increased Expression of PITX2, LEF-1, $\beta$-Catenin in Epithelial Ovarian Cancer. J Cytol Histol 6: 333. doi:10.4172/2157-7099.1000333

Page 4 of 6

\begin{tabular}{|c|c|c|c|c|c|c|c|c|c|c|}
\hline Group & $n$ & & PITX2 & & & LEF-1 & & & $\beta$-catenin & \\
\hline & & $+(\%)$ & $x^{2}$ & $P$-value & $+(\%)$ & $x^{2}$ & $P$-value & $+(\%)$ & $x^{2}$ & $P$-value \\
\hline Total & 42 & & & & & & & & & \\
\hline \multicolumn{11}{|l|}{ Age } \\
\hline$<50$ & 20 & $16(80)$ & 0.019 & 0.890 & $14(70)$ & 0.287 & 0.592 & $16(80)$ & 0.322 & 0.057 \\
\hline$>50$ & 22 & $19(86.36)$ & & & $18(81.82)$ & & & 20(90.91) & & \\
\hline \multicolumn{11}{|l|}{ Grade } \\
\hline G1-G2 & 13 & $8(61.54)$ & 4.367 & 0.037 & $7(53.85)$ & 5.182 & 0.023 & $8(61.54)$ & 4.355 & 0.012 \\
\hline G3 & 29 & $27(93.1)$ & & & $25(86.21)$ & & & $28(96.55)$ & & \\
\hline \multicolumn{11}{|l|}{ Stage } \\
\hline I+ II & 15 & $9(60)$ & 6.720 & 0.01 & $8(53.33)$ & 4.903 & 0.027 & $10(66.67)$ & 4.706 & 0.03 \\
\hline III + IV & 27 & $26(96.3)$ & & & $24(88.89)$ & & & $26(96.3)$ & & \\
\hline \multicolumn{11}{|c|}{$\begin{array}{l}\text { Lymph node } \\
\text { metastasis }\end{array}$} \\
\hline with & 26 & $25(96.15)$ & 5.836 & 0.016 & $23(88.46)$ & 4.029 & 0.045 & $25(96.15)$ & 4.043 & 0.044 \\
\hline without & 16 & $10(62.5)$ & & & $9(56.25)$ & & & 11(68.75) & & \\
\hline
\end{tabular}

Table 3: Relations between abnormal expressions of PITX2, LEF-1, $\beta$-catenin proteins and clinical pathological features of epithelial ovarian cancer.

\begin{tabular}{|c|c|c|c|c|}
\hline Group & $\mathbf{n}$ & PITX2 mRNA & LEF-1 mRNA & $\beta$-catenin mRNA \\
\hline Cancer group & 42 & $0.286 \pm 0.106^{* \#}$ & $0.504 \pm 0.116^{* \#}$ & $0.405 \pm 0.126^{* \#}$ \\
\hline Benign group & 37 & $0.132 \pm 0.095^{\Delta}$ & $0.241 \pm 0.112^{\Delta}$ & $0.167 \pm 0.106^{\Delta}$ \\
\hline Normal group & 35 & $0.110 \pm 0.082$ & $0.223 \pm 0.097$ & $0.128 \pm 0.087$ \\
\hline$F$ & & 40.569 & 82.921 & 75.414 \\
\hline$P$ & & $<0.001$ & $<0.001$ & $<0.001$ \\
\hline
\end{tabular}

Annotation: $\Delta$ compared with Normal ovarian group, $P>0.05$; " compared with benign ovarian tumors and normal ovarian tissues respectively, $P<0.01$.

Table 4: The mRNA expressions of PITX2, LEF-1, $\beta$-catenin in different ovarian tissues.

\begin{tabular}{|c|c|c|c|}
\hline Group & n & PITX2 & F \\
\hline Epithelial ovarian cancer group & 42 & $12.18 \pm 2.38$ & \\
\hline Benign ovarian tumor group & 37 & $7.83 \pm 1.9$ & \\
\hline Normal ovarian group & 35 & $7.25 \pm 2.24$ & 59.66 \\
\hline
\end{tabular}

Table 5: The preoperative serum level of PITX2 in epithelial ovarian cancer group, benign ovarian tumor group and normal ovarian group ( $\bar{\chi} \pm \mathrm{s}$ ng/ml)

compared to the control group by MTT and cell scratch test $(\mathrm{P}<0.05)$ ,however, the SKOV3 cells weakened more obvious compared with OVCAR3 cells (Figures 2A and 2B).

\section{DKK1 inhibits the express of PITX2, LEF-1 and $\beta$-catenin in ovarian cancer cells}

Given that Pitx2 gene Expression was induced by the Wnt $/ \beta$ Catenin Pathway, there is a certain relationship between the three genes of PITX2、LEF-1 and $\beta$-catenin. To test this notion, we selected two cells (skov3 and ovcar3). When the cells turned into logarithmic phase, DKK $130 \mathrm{ng} / \mathrm{ml}$ was added. We found out that not only the cells of Proliferation and migration were weakened, but also the mRNA and prorien of PITX2, LEF- 1 and $\beta$-catenin all decreased respectively compared to their scrambled control $(\mathrm{P}<0.05)$. Collectively, these data suggest that there is no wnt pathway, the transcriptional activity of PITX2 is decline (Figures $3 \mathrm{~A}$ and $3 \mathrm{~B}$ ).

\section{Discussion}

PITX2 involved in embryonic development, which has been studied extensively. Recently, there have been increasing reports showing that PITX2 is overexpressed in human cancers such as nonfunctional pituitary adenomas [18], Wilms tumor [19], Breast cancer [20] and node-positive colorectal cancer [21]. However, the functional roles of PITX2 in human cancers such as ovarian cancer remain unknown.
Previous studies have pointed out that PITX2 is one of the downstream effectors of $\mathrm{Wnt} / \mathrm{b}$-catenin pathway [10-12]. There is no report show any relationship of Wnt/ $\beta$-catenin signaling, PITX2 and LEF-1 expression in ovarian cancer. Our study showed that both mRNA and protein levels of PITX2 were frequently upregulated in ovarian cancer compared to benign ovarian tumors and normal ovaries using Q-PCR and IHC analyses. It has associated with clinical stage, histological grade and lymph node metastasis, yet there was no significant associated with age and pathological type. The higher the stage is, the high express of PITX2 is. That indicates that PITX2 may play an important role in ovarian cancer. In this study, we firstly demonstrated that PITX2 was frequently upregulated in ovarian cancers serum,, suggesting that it may be associated with tumor cell's abnormal increased. Thus, screening the express of PITX2 in Patient's serum will not only help with ovarian cancer early detection and early treatment, but also has great significance for postoperative follow-up of ovarian cancer patients.

malignancies. Recent In addition, previous studies have pointed out that PITX2 is one of the downstream effectors of Wnt/b-catenin pathway, Wnt $/ \beta$-catenin can regulate the PITX2 promoter [2].The study found that in SKOV3 and OVCAR3 cells, when adding inhibitor DKK1, the expression of protein and mRNA in PITX2,LEF-1 and $\beta$-catenin were decreased compared to the control group, . when the expression of PITX2 was decreased, thereby inhibiting the proliferation and differentiation of cells.O was added 
Citation: Guo H, Zhu H, Zhao S, Zhang M, Liu X, et al. (2015) Increased Expression of PITX2, LEF-1, $\beta$-Catenin in Epithelial Ovarian Cancer. J Cytol Histol 6: 333. doi:10.4172/2157-7099.1000333

A
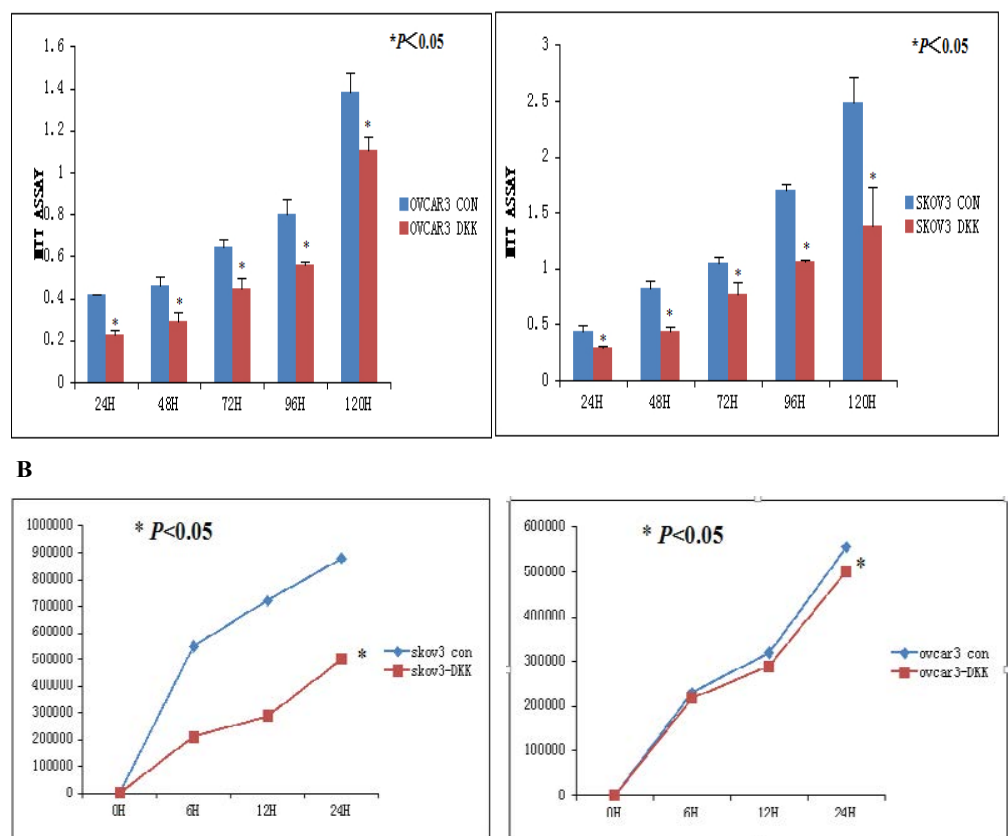

Figure 2: $(\mathrm{A}$ and $\mathrm{B})$ After added $\mathrm{DKK}_{1}$, the proliferation and migration of SKOV3 and OVCAR3 as compared with their vector control.
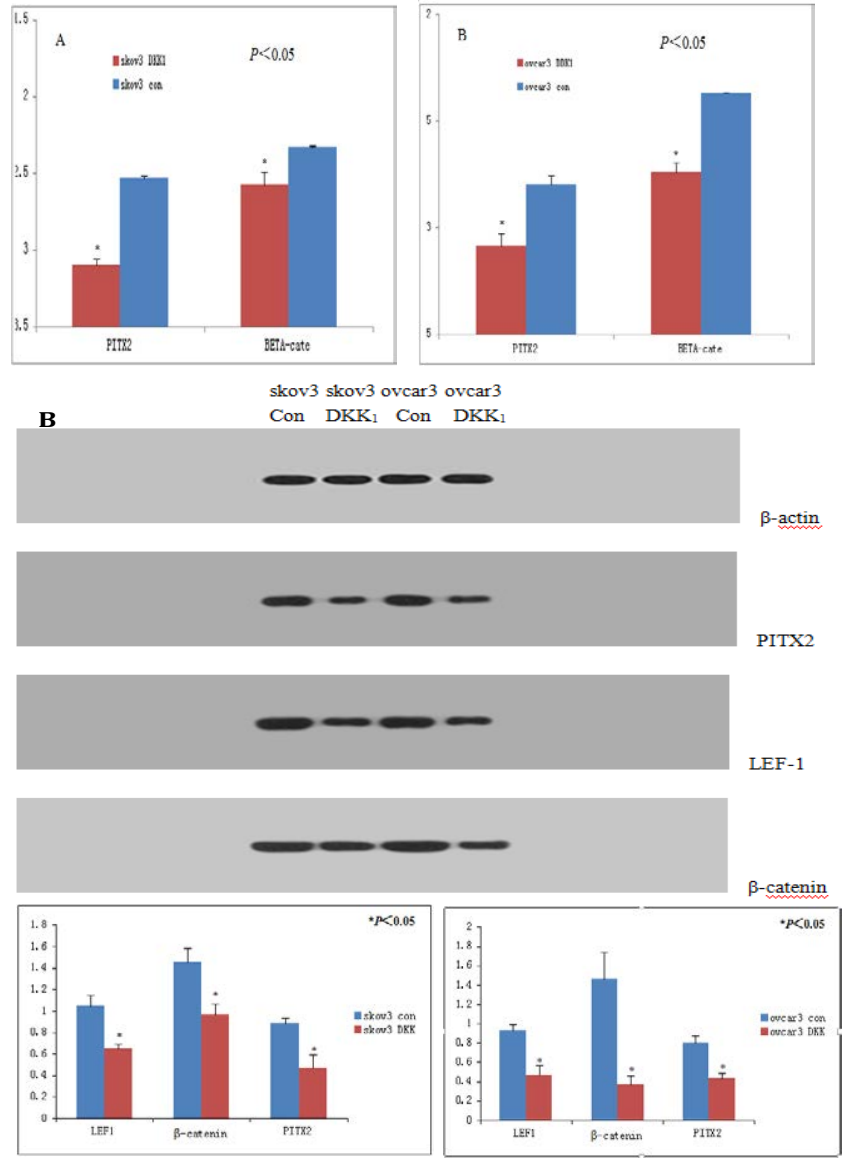

Figure 3: (A) The mRNA of PITX2、LEF-1 and $\beta$-catenin all decreased respectively as compared with their scrambled control, when added the inhibitor of DKK 1 . $(B)$ Western blot analysis using anti-PITX2 antibody, anti-LEF-1 antibody and anti- $\beta$-catenin antibody showed the reduced expressions of PITX2 , LEF-1 and $\beta$-catenin by the inhibitor of $\mathrm{DKK}_{1}$. 
Citation: Guo H, Zhu H, Zhao S, Zhang M, Liu X, et al. (2015) Increased Expression of PITX2, LEF-1, $\beta$-Catenin in Epithelial Ovarian Cancer. J Cytol Histol 6: 333. doi:10.4172/2157-7099.1000333

Page 6 of 6

In summary, from the tissue and cell level, our findings suggest that PITX2, LEF-1 and $\beta$-catenin play important roles in ovarian cancer progression by promoting tumor growth and migration in ovarian cancer. PITX2 is involved in the occurrence and development of epithelial ovarian cancer and PITX2 may act as downstream target genes in the Wnt $/ \beta$-catenin signaling pathway, which is regulated by $\mathrm{Wnt} / \beta$-catenin. There may be the same mechanism of action and the pituitary and teeth. If we could find effective drugs for inhibiting tumor growth, this may provide new ideas for epithelial ovarian cancer patients.

\section{References}

1. Ai D, Wang J, Amen M, Lu MF, Amendt BA, et al. (2007) Nuclear factor 1 and T-cell factor/LEF recognition elements regulate Pitx2 transcription in pituitary development. Mol Cell Biol 27: 5765-5775.

2. Kioussi C, Briata P, Baek SH, Rose DW, Hamblet NS, et al. (2002) Identification of a Wnt/Dvl/ß-catenin? PITX2 pathway mediating cell type-specific proliferation during development. Cell 111: 673-685.

3. Lin CR, Kioussi C, O'Connell S, Briata P, Szeto D, et al. (1999) Pitx2 regulates lung asymmetry, cardiac positioning and pituitary and tooth morphogenesis. Nature 401: 279-282

4. Vadlamudi U, Espinoza HM, Ganga M, Martin DM, Liu X, et al. (2005) PITX2, beta-catenin and LEF-1 interact to synergistically regulate the LEF-1 promoter. J Cell Sci 118: 1129-1137.

5. Farley J, Ozbun LL, Birrer MJ (2008) Genomic analysis of epithelial ovarian cancer. Cell Res 18: 538-548.

6. Karst AM, Drapkin R (2010) Ovarian cancer pathogenesis: a model in evolution J Oncol 2010: 932371

7. Fung FK, Chan DW, Liu VW, Leung TH, Cheung AN, et al. (2012) Increased expression of PITX2 transcription factor contributes to ovarian cancer progression. PLoS One 7: e37076.

8. Amendt BA, Semina EV, Alward WL (2000) Rieger syndrome: a clinical, molecular, and biochemical analysis. Cell Mol Life Sci 57: 1652-1666.

9. Hjalt TA, Semina EV, Amendt BA, Murray JC (2000) The Pitx2 protein in mouse development. Dev Dyn 218: 195-200.

10. Kioussi C, Briata P, Baek SH, Rose DW, Hamblet NS, et al. (2002) Identification of a Wnt/Dvl/beta-Catenin --> Pitx2 pathway mediating cell-type-specific proliferation during development. Cell 111: 673-685.

11. Baek SH, Kioussi C, Briata P, Wang D, Nguyen HD, et al. (2003) Regulated subset of $\mathrm{G} 1$ growth-control genes in response to derepression by the Wnt pathway. Proc Natl Acad Sci U S A 100: 3245-3250.

12. Ganga M, Espinoza HM, Cox CJ, Morton L, Hjalt TA, et al. (2003) PITX2 isoform-specific regulation of atrial natriuretic factor expression: synergism and repression with Nkx2.5. J Biol Chem 278: 22437-22445.

13. Guo Y, Xie J, Zi X (2009) Wnt signaling regulates S100A4 to mediate metasis of osteosarcoma. Proc Am Assoc Cancer Res 50: 531-532.

14. Zhang F, Zhang L, Zhang B, Wei X, Yang Y, et al. (2009) Anxa2 plays a critical role in enhanced invasiveness of the multidrug resistant human breast cancer cells. J Proteome Res 8: 5041-5047.

15. Cortesi L, Barchetti A, De Matteis E, Rossi E, Della Casa L, et al. (2009) Identification of protein clusters predictive of response to chemotherapy in breast cancer patients. J Proteome Res 8: 4916-4933.

16. Han A, Song Z, Tong C, Hu D, Bi X, et al. (2008) Sulindac suppresses betacatenin expression in human cancer cells. Eur J Pharmacol 583: 26-31.

17. Demunter A, Libbrecht L, Degreef H, De Wolf-Peeters C, van den Oord $\mathrm{JJ}$ (2002) Loss of membranous expression of beta-catenin is associated with tumor progression in cutaneous melanoma and rarely caused by exon 3 mutations. Mod Pathol 15: 454-461.

18. Moreno CS, Evans CO, Zhan X, Okor M, Desiderio DM, et al. (2005) Nove molecular signaling and classification of human clinically nonfunctional pituitary adenomas identified by gene expression profiling and proteomic analyses. Cancer Res 65: 10214-10222.

19. Zirn B, Samans B, Wittmann S, Pietsch T, Leuschner I, et al. (2006) Target genes of the WNT/beta-catenin pathway in Wilms tumors. Genes Chromosomes Cancer 45: 565-574.

20. Nimmrich I, Sieuwerts AM, Meijer-van Gelder ME, Schwope I, Bolt-de Vries $\mathrm{J}$, et al. (2008) DNA hypermethylation of PITX2 is a marker of poor prognosis in untreated lymph node-negative hormone receptor-positive breast cancer patients. Breast Cancer Res Treat 111: 429-437.

21. Meeh PF, Farrell CL, Croshaw R, Crimm H, Miller SK, et al. (2009) A gene expression classifier of node-positive colorectal cancer. Neoplasia 11: 1074-1083. 